\section{BMIJ}

ISSN: 2148-2586

\author{
Vol.:7 Issue:2 Year: 2019, pp. 579-590
}

Citation: Yorulmaz M. \& Sabırlı H. (2019), Sağlik Hizmetleri Arzinda Defansif Tip Ve Hekimlerin Karar Verme Algisi, BMIJ, (2019), 7(2): 579-590 doi: http://dx.doi.org/10.15295/bmij.v7i2.1121

\title{
SAĞLIK HİZMETLERİ ARZINDA DEFANSİF TIP VE HEKIMLERIN KARAR VERME ALGISI
}

Mehmet YORULMAZ ${ }^{1}$

Hatice SABIRLI ${ }^{2}$
Received Date (BaşvuruTarihi): 22/01/2019

Accepted Date (Kabul Tarihi): 08/03/2019

Published Date (YayınTarihi): 26/06/2019

\section{$\ddot{O} Z$}

Amaç: Bu çalışmada, sağllk hizmetleri arzında defansif tıp ve hekimlerin karar verme algıları arasındaki ilişsinin incelenmesi amaçlanmıştır.

Gereç ve Yöntem: Araşttrma, Konya ilinde 4 özel hastenede görev yapmakta olan hekimler üzerinde uygulanmıştır. Nicel araştırma deseni kullanılan araşttrmaya 32 kadın 70 erkek olmak üzere toplam 102 hekim katılmıştır. Araş̧trmada örneklem grubunun oluşturulmasında kolayda örneklem yöntemi, verilerin toplanmasında ise anket tekniği kullanılmıştır. Çalı̧̧mada demografik bilgileri içeren "kişisel bilgi formu" kullanılmuştır. Hekimlerin karar verme algilarını ölçmek için Scott ve Bruce (1995) tarafindan geliştirilen Taşdelen (2002) tarafindan Türkçeye uyarlanan Karar Verme Stilleri Ölçeği ile birlikte hekimlerin defansif tıp tutumlarını ölçmek amacıyla Başer ve Ark. (2014) tarafindan geliştirilen Defansif Tip Tutum Ölçeği kullanılmıştır.

Bulgular: Araştırmaya katılan hekimlerin \%31,4'i kadın, \%68,6'sı erkektir. Katıllmcıların \%39,2'si 3544 yaş aralı̆̆ındadır. Çalışllan birimlere baktı̆̆ımızda hekimlerin çoğu \%44,1 ile dahili birimlerde çalışmaktadır. Katıllmcıların \%60,8'i 11 yll ve üstü süre hekimlik yaptı̆̆ görülmüştür. Çocuk saylsı incelendiğinde \%39,2'inin 2 çocuk sahibi olduğu görülmüştür. Karar verme ile defansif tip arasinda negatif yönde düşük düzeyde anlaml bir iliş̧k tespit edilmişstir. Hekimlerin karar verme ile defansif tıp tutumları arasindaki ilişki incelenmiş ve sonucunda karar verme stilleri ile defansif ttp arasinda negatif yönde düşük düzeyde anlamlı bir ilişki tespit edilmiştir $(r=-, 229 ; p<0,05)$. Defansif top ile karar verme puan ortalamalart ile cinsiyet ve medeni durum değişkenleri arasında bağımsı gruplarda t testi analizi yapılmış ve anlaml farklllık görülmemiş̧ir. Çalışmamıza katılan hekimlerden "Hekimlik mesleğiniz sürecinde malpraktis nedeni ile dava açıldı mı" sorusuna 13 hekim $(\% 2,7)$ evet cevabını verirken, 89 hekim $(\% 87,3)$ hayır cevabı vermişstir. Defansif tıp uygulamaları kavramını içeriği konusunda yeterli bilgiye sahip misiniz? sorusuna 56 hekim $(\% 54,9)$ "hayır" cevabınt vermiştir.

Sonuç: Araştırmamızın sonuçlarına göre hekimler defansif tıp konusunda yeterli bilgiye sahip değildir ve defansif tıp davranışı gösterme eğilimleri fazladır.

Anahtar Kelimeler: Defansif Tip; Malpraktis; Karar Verme

Jel Kodu: I1, M1, KO

\footnotetext{
${ }^{1}$ Dr. Öğretim Üyesi, Selçuk Üniversitesi mtyorulmaz@hotmail.com

${ }^{2}$ Master Öğrencisi, Selçuk Üniversitesi htcsbrli@gmail.com,
}

http://orcid.org/0000-0001-6670-165X http://orcid.org/0000-0002-3074-1577 


\title{
THE PERCEPTION OF PHYSICIANS ON DEFENSIVE MEDICINE AND DECISION-MAKING IN SUPPLY OF HEALTH CARE SERVICES
}

\begin{abstract}
Objective: The aim of this study was to investigate the relationship between defensive medicine and the decision-making perceptions of physicians in the supply of health services.

Materials and Methods: In this study, four different private hospitals in the province of Konya were applied to the prescribing physicians. Using qualitative research design, 102 physicians, 32 females and 70 males, participated in the study. Sampling method was used to create the sample group and the survey technique was used to collect the data. In the study, 'personal information form' containing demographic information was prepared. In order to measure the perception of physicians' decision making, the Decision-Making Styles Scale, which was developed by Scott and Bruce (1995) and adapted by Taşdelen (2002) was used. Defensive Medical Attitude Scale, which was developed Başer et al. (2014) was used.

Results: Of the participating physicians, $31.4 \%$ were female and $68.6 \%$ were male. $39.2 \%$ of the participants were in the 35-44 age range. Considering the units studied, most of the physicians work in internal units as 44.1\%. It was observed that $60.8 \%$ of the participants were doctors with the experience of 11 years or more. As far as the parentage rates are concerned, it is found that $39.2 \%$ have 2 children. A negative low rate correlation was found between the decision making and defensive medicine. The relationship between the decision making and defensive medicine attitudes of physicians was examined and as a result, there was a low negative correlation between decision-making styles and defensive medicine ( $r=-.229 ; p<0.05)$. T test analysis was performed in interdependent groups, no significant difference was observed among defensive medicine and decision-making mean scores, and sex and marital status variables.13 physicians (2.7\%) answered in the affirmative to the question of "Is there a case for malpractice in the process of your medical profession?" 56 physicians (54.9\%) answered negatively to the question "Do you have enough information about the contents of the concept of defensive medical practice?"
\end{abstract}

Conclusion: According to the results of our study, physicians do not have enough knowledge about defensive medicine and they have a tendency to show depressive medicine behavior.

Keywords: Defensive Medicine; Malpractice; Decision Making

Jel Code: $11, M 1, K O$

\section{GíRiş}

Günümüzde meslek mensupları mesleklerini icra ederken, bireysel veya mesleğin kendisinden kaynaklı bazı hatalar yapabilmektedirler. Bu hatalar Sağlık hizmeti sunumunda yapılan hatalar bazen geri dönüşü olmayan sonuçlara sebep olabilmektedirler. $\mathrm{Bu}$ sonuçlar insanların zarar görmesine hatta ölmesine sebep olabilmektedirler. Sağlık hizmetleri hayati öneme sahip, hata kabul etmeyen, insan hayatını doğrudan ilgilendiren bir alandır. Bu yüzden bu hizmeti sunan hekim, hemşire ve diğer sağlık personellerinin hizmet sunumunda çok dikkatli olmaları gerekmektedir. Hekim ve hasta arasında bir ilişki vardır. $\mathrm{Bu}$ ilişki hastanın muhtaçlığı ve hekimin bilgisi üzerine kurulmuştur. Taraflar arasındaki bu eşitsizlik asimetrik bilgi kavramını doğurmaktadır. Asimetrik bilgi, 
karşılıklı fayda sağlayan bir ilişkide tarafların birinin diğerine muhtaç, sahip olduğu bilgisinden dolayı muhtaç olması durumudur. Sağlık sektöründe bu durum en çok hasta ve hekim arasında yaşanmaktadır.

Dünya genelinde yaşanan tıbbi hatalar tahmin edilenden çok daha fazladır. Örneğin; uçağa binen kişinin uçak kazasında ölme riski 1/1000.000 olmasına rağmen, sağlık hizmeti almak için sağlık kuruluşuna başvuran bir kişinin tıbbi bir hata nedeniyle zarar görme riski: 1/300’dür. (Nul vd., 2003, Akt: Oval1, 2010).

Sağlık profesyonellerinin maruz kaldıkları cezalardaki artış, herkes tarafından geniş çapta kabul gören bir endişe kaynağ 1 haline gelmiştir. Sigorta şirketleri ve hastalar, tıbbi hatalar hakkında daha iyi bilgi sahibidirler. Onlar sunulan sağlık hizmetlerini miktar, kalite ve tedavi açısından değerlendirebilmektedirler (Miller,2006). Tıbbi hatalardan kaynaklı davaların ve hukuki cezaların sağlık hizmeti maliyetlerini artırdığ bilinmektedir (White, 2005). Tıbbi yanlış tedavi primleri ve sigorta şirketi ödemeleri çok yüksektir. İşte bu durum hekimleri defansif tıp uygulamasına mecbur bırakmaktadır (Conroy, 2006). Defansif tıp kısaca; "hekimin ceza veya hukuk davalarıyla karşılaşmamak, tazminat ödememek, sigorta poliçe primlerini artırmamak amacıyla aşırı korumacı veya çekingen davranarak tanı ve tedaviye yönelik tıbbi uygulamaları gereksiz kullanması ve malpraktis davası ile sonuçlanma riski yüksek olan uygulamalardan kaçınması” şeklinde tanımlanabilir (Aynacı, 2008).

Defansif tıp kötü bir tıp çeşididir. Doktorun potansiyel riske maruz kalmasını azaltır, fakat aynı zamanda hastayı gerekli işlem riskine maruz bırakır. Hekim gerekli olan istemde bulunmaz. Doktorların tazminata maruz kalma korkusu onların motivasyonunu azaltır. Bir anda doktorlar, mahkemede hasta karşısında "savunmacı" durumuna düşebilirler (Panting, 2005). Bu durum hekimleri tedavi için gerekli işlemleri yapmaktan alıkoyabilmektedir.

Defansif tıp aynı zamanda faydalı da olabilmektedir. Tıbbi müdahale ve tedaviden doğan malpraktise ilişkin hukuki ve cezai sorumluluğunu bilen bir hekim, tıbbi müdahale esnasında daha etkin ve verimli olacak böylelikle sırf aleyhlerine açılacak davalardan çekinerek yüksek riskli hastaları tedavi etmekten kaçınma veya aşırı tanı isteminde bulunmayacaktır. $\mathrm{Bu}$ açıdan bakıldığında hekimlerin hukuki ve cezai sorumluluklarına ilişkin farkındalık düzeylerini arttırmanın faydası sadece hekimi hukuk karşısında 
korumakla sınırlı kalmayacak, hasta güvenliği ve hasta hakları açısından da ilerleme kaydettirecektir (Dedeoğlu, 2012).

Defansif tıbbı iki başlık altında değerlendirmek mümkündür. Studdert ve ark. (2005) defansif tıbbi "pozitif defansif tıp" ve "negatif defansif tıp" olarak iki şekilde tanımlamışlardır. Pozitif defansif tıp, güvence davranışı ya da savunma tıbbı da denilen bu kavram, marjinal veya tıbbi değeri olmayan olumsuz sonuçları azaltmak için, hastaları yanlış uygulamalardan caydırmak amacıyla, yasal sistemi ikna etmek için tıbbi değer taşımayan davranışları içermektedir

Pozitif defansif tıp, gerekli olan uygulamaları eksiksiz yapma ve gerekmese de hekimin kendini savunmada güçlendirmek için uygulamalar yapma uğraşıdır. Bunlar çok çeşitli yollarla yerine getirilir. Negatif defansif tıp ise; yapılması gereken uygulamalardan kaçınma yoluyla gerçekleşir. Bu iki kavramı daha iyi ayırt edebilmek için tablo 1'deki örnekleri verilmiştir;

Tablo 1. Pozitif ve Negatif Defansif T1p Uygulamaları

\begin{tabular}{|l|l|}
\hline Pozitif Defansif Tıp Uygulamaları & Negatif Defansif Tıp Uygulamaları \\
\hline Gereksiz Hasta Yatırılması & Riskli Hastalardan Kaçınma \\
\hline Gereksiz Tahlil İstenmesi & Riskli Tedavi Yöntemlerinden Kaçınma \\
\hline Gereksiz Görüntüleme ve İlaç İstenmesi & Riskli İnceleme Yöntemlerinden Kaçınma \\
\hline Gereksiz Vizit Yapmak ve Konsültasyon İstemi & Riskli Cerrahi Girişimlerden Kaçınma \\
\hline Gereksiz Ameliyat Yapmak & Riskli Hastaları Başka Kuruluşa Sevk Etmek \\
\hline $\begin{array}{l}\text { Hasta ve Yakınlarının memnuniyeti ve } \\
\text { Bilgilendirilmelerine Aşırı İlgi Gösterme }\end{array}$ & $\begin{array}{l}\text { Riskli Hastaların Gözün Korkutup Başka } \\
\text { Kuruluşa Gitmesini Sağlamak }\end{array}$ \\
\hline $\begin{array}{l}\text { Ayrıntılı Kayıt Tutmak ve Onam Formlarına } \\
\text { Aşrı Özen Göstermek }\end{array}$ & $\begin{array}{l}\text { Riskli Hastaları Başka Sağlık Kuruluşlarına } \\
\text { Överek Kaçırmak }\end{array}$ \\
\hline $\begin{array}{l}\text { Olumsuzlukları Ayrıntılı Olarak Kayıt Altına } \\
\text { Almak }\end{array}$ & $\begin{array}{l}\text { Girişimlerden Önce Olası Bir Olumsuzlukta } \\
\text { Hasta ve Yakınlarının Tepkisinden Kaçınma }\end{array}$ \\
\hline
\end{tabular}

Tablo 1'de görüldüğü üzere negatif defansif uygulamalar daha çok hekimlerin yasal risklerden korunmak için yaptıkları uygulamaları içermektedir. Pozitif defansif tıpta ise; hekim kendini korumak için tıbben gerekmeyen işlemler yapar, gerekli işlemleri abartarak yapar ya da daha önce yeterince göstermediği özen borcu üzerinde daha çok durur (Selçuk, 2015).

$\mathrm{Bu}$ çalışmada, hekimlerin defansif tıp gösterme nedenleri ve karar verme algıları incelenmiştir. 


\section{YÖNTEM}

Bu çalışmada Konya ilinde 4 farklı özel hastanede görev yapan hekimlerin defansif tıp ve karar verme algıları arasındaki ilişkinin incelenmesi amaçlanmıştır. Çalışmada nicel araştırma deseni kullanılmış olup yüz yüze anket yönteminden yararlanılmıştır. Araştırma evrenini bu 4 özel hastanede "cerrahi bilimler, dâhili bilimler ve temel tıp bilimleri" alanında görev yapan hekimler oluşturmaktadır. Araştırmada örneklem büyüklüğünün belirlenebilmesi için Altunışık ve ark. (2012) tarafından oluşturulan belirli evrenler için kabul edilebilir örneklem büyüklükleri tablosundan yararlanılmıştır. Araştırmanın evrenini 110 kişi oluşturmaktadır. Örneklem için 86 kişilik örneklem büyüklüğü yeterli olup 105 kişi çalışma kapsamına dahil edilmiştir. Ancak 3 anketteki eksik bilgilerden dolayı veri analizi 102 anket üzerinden SPSS 25.0 paket programı kullanılarak yapılmıştır. Araştırmada 2 farklı ölçek kullanılmış olup araştırma hastane yönetimlerinden izin alınarak tamamen gönüllülük esası çerçevesinde yapılmıştır. Analizlerde parametrik test tekniklerinden ikili karşıllaştırmalar için Independent Samples t-Testi, ikiden fazla grupların karşılaştırılması için One-way ANOVA testi yapılmıştır.

İlk bölümde oluşturulan soru formunda, araştırmaya katılanların sosyo-demografik özellikleri yer almaktadır. İkinci bölümde, hekimlerin karar verme algılarını belirlemek amacıyla Scott ve Bruce (1995) tarafından geliştirilen Taşdelen (2002) tarafından Türkçe'ye uyarlanan Karar Verme Stilleri Ölçeği yer almaktadır. Ölçekte her madde 1 'kesinlikle katılmıyorum' ve 5 'kesinlikle katılıyorum' arasında yer alan beşli dereceleme likert türü ile hazırlanmıştır. Araştırmada kullanılan 5 alt boyut ve bu boyutlarla ilgili madde sayıları şöyledir: Birinci boyut olan "rasyonel karar verme" alt boyutu ile ilgili 5, "sezgisel karar verme" alt boyutu ile ilgili 5 "kaçınma karar verme" alt boyutu ile ilgili 5, "kendiliğindenanlık karar verme", alt boyutu ile ilgili 5, "bağımlı karar verme" alt boyutu ile ilgili 5 ifade içermektedir. Ölçek toplamda 25 ifadeden oluşmaktadır.

Üçüncü bölümde ise Başer ve arkadaşları tarafından 2014 yılında defansif tıp tutum düzeyinin belirlenmesi amacı ile geliştirilen "Defansif Tıp Tutum Ölçeği” yer almaktadır. Söz konusu ölçek likert tarzda oluşturulmuştur. Ölçek pozitif defansif tıp, negatif defansif tıp ve bilgi düzeyi alt boyutlarından oluşmaktadır. Birinci boyut olan "pozitif defansif tıp" alt boyutu ile ilgili 9, "negatif defansif tıp" alt boyutu ile ilgili 5 "bilgi düzeyi" alt boyutu ile ilgili 4 madde içermektedir. Ölçek toplamda 18 ifadeden oluşmaktadır. Araştırmada kullanılan ölçeklerin Cronbach's Alpha değerlerine bakılmış ve Karar Verme Ölçeğinde 
Cronbach's alfa katsayısı 0,727; Defansif Tıp Ölçeğinde ise 0,789 olarak yüksek düzeyde çıkmıştır.

Tablo 2. Araştırmada Kullanılan Ölçeklere Ait Cronbach's Alpha Değerleri

\begin{tabular}{lcc}
\hline Ölçekler & Soru Sayısı & Cronbach's Alpha \\
\hline Karar Verme Ölçeği & 25 & 0,727 \\
Defansif Tıp Ölçeği & 18 & 0,789 \\
\hline
\end{tabular}

Tablo 2'de görüldüğü gibi, karar verme ölçeği ve defansif tıp ölçeği için Cronbach alfa değerleri kabul edilebilir değeri olan .70 değerinin üzerinde bulunmuştur.

\section{BULGULAR}

Bu çalışmadan elde edilen bulguların istatistiksel analizleri yapılarak sonuçları tablolar halinde aşağıda sunulmuştur.

Tablo 3. Araştırmaya Katılan Hekimlere Ait Demografik Veriler

\begin{tabular}{|c|c|c|c|}
\hline \multicolumn{2}{|c|}{ Tanımlayıcı Özellikler } & \multirow{2}{*}{$\frac{\mathbf{n}}{1}$} & \multirow{2}{*}{$\begin{array}{c}\% \\
1\end{array}$} \\
\hline \multirow{4}{*}{ Yaş } & $18-24$ & & \\
\hline & $25-34$ & 29 & 28,4 \\
\hline & $35-44$ & 40 & 39,2 \\
\hline & 45 ve üstü & 32 & 31,4 \\
\hline \multirow{2}{*}{ Medeni Durum } & Evli & 82 & 80,4 \\
\hline & Bekar & 20 & 19,6 \\
\hline \multirow{2}{*}{ Cinsiyet } & Kadın & 32 & 31,4 \\
\hline & Erkek & 70 & 68,6 \\
\hline \multirow{3}{*}{ Çalışılan Birim } & Dahili Birimler & 45 & 44,1 \\
\hline & Cerrahi Birimler & 40 & 39,2 \\
\hline & Temel Tip Bilimleri & 17 & 16,7 \\
\hline \multirow{3}{*}{ Kurumda çalışma Süresi } & 1 Yildan $\mathrm{Az}$ & 25 & 24,5 \\
\hline & $1-5 Y_{11}$ & 53 & 52 \\
\hline & 6 Yil ve Üstü & 24 & 23,5 \\
\hline \multirow{3}{*}{ Hekim olarak çalışma süresi } & $0-5$ Yil & 14 & 13,7 \\
\hline & 6-10 Y1l & 26 & 25,5 \\
\hline & 11 Y1l ve Üstü & 62 & 60,8 \\
\hline \multirow{4}{*}{ Çocuk sayısı } & Yok & 29 & 28,4 \\
\hline & 1 Çocuk & 16 & 15,7 \\
\hline & 2 Çocuk & 40 & 39,2 \\
\hline & 3 Çocuk & 17 & 16,7 \\
\hline
\end{tabular}

Tablo 3' de görüldüğü üzere katılımcıların \%39,2'si 35-44 yaş aralığındadır. Aynı katılımcıların \%80,4'ü evlidir. Araştırmaya katılan hekimlerin \%31,4'i kadın, \%68,6'sı 
erkektir. Çalışılan birimlere bakıldığında hekimlerin çoğu \%44,1 ile dahili birimlerde çalışmaktadır. Katılımcıların \%60,8'inin 11 yıl ve üstü süre hekimlik yaptığı görülmüştür. Ayrıca hekimlerin \%52'si 1-5 yıl ara ile şu an çalıştıkları kurumda çalışmaya devam ettikleri tespit edilmiştir. Son olarak ise kurumda çalışmakta olan hekimlerin çocuk sayısı incelendiğinde \%39,2'inin 2 çocuk sahibi olduğu \%28,4'sinin de çocukları olmadığ görülmektedir.

Tablo 4. Normallik Testi Sonuçları

Ölçekler

Defansif Tip

Karar Verme
Kolmogorov-Smirnov

İstatistik $\quad \mathrm{n} \quad \mathrm{p}$

,071

, 054

102
102

,200

Shapiro-Wilk

\begin{tabular}{ccc} 
İstatistik & $\mathrm{n}$ & $\mathrm{p}$ \\
, 991 & 102 &, 712 \\
, 991 & 102 &, 717 \\
\hline
\end{tabular}

Analizlerde kullanılacak test tekniklerini belirlemek için yapılan normallik testi analiz sonuçları yukarıdaki Tablo 4'de gösterilmektedir. Normallik testi sonucunda $p>0,05$ ve dağılım normal dağılım gösterdiği için parametrik test tekniklerine göre analiz yapılmıştır.

Tablo 5. Araştırmaya Katılan Hekimlerin Cinsiyeti ve Medeni Durumları ile Karar Verme Stilleri ve Defansif Tıp Puan Ortalamaları Arasında Bağımsız Gruplarda t-Testi Analizi

\begin{tabular}{|l|l|c|c|c|c|c|}
\hline Ölçek & \multicolumn{1}{|c|}{ Cinsiyet } & n & Ort. & SS & t & p \\
\hline \multirow{2}{*}{ Karar Verme Algısı } & Kadın & 32 & 3,1788 & 0,25823 & \multirow{2}{*}{1,735} & \multirow{2}{*}{0,086} \\
\cline { 2 - 6 } & Erkek & 71 & 3,0503 & 0,38013 & & \\
\hline \multirow{2}{*}{ Defansif Tıp } & Kadın & 32 & 2,6215 & 0,49256 & \multirow{2}{*}{0,055} & \multirow{2}{*}{0,956} \\
\cline { 2 - 5 } & Erkek & 71 & 2,6270 & 0,45066 & & \\
\hline
\end{tabular}

Tablo 5'te görüldüğü üzere cinsiyet ile karar verme ve cinsiyet ile defansif tıp arasında t testi analizi yapılmıştır. Analiz sonucuna göre; cinsiyet ile karar verme ve cinsiyet ile defansif tıp arasında anlamlı bir fark olmadığı tespit edilmiştir ( $p>0,05)$.

Tablo 6. Araştırmaya Katılan Hekimlerin Medeni Durumları ile Karar Verme Stilleri ve Defansif Tıp Puan Ortalamaları Arasında Bağımsız Gruplarda t-Testi Analizi

\begin{tabular}{|l|l|c|c|c|c|c|}
\hline \multirow{2}{*}{$\begin{array}{l}\text { Karar Verme } \\
\text { Algısı }\end{array}$} & Evli & 82 & 3,0922 & 0,36826 & \multirow{2}{*}{0,093} & \multirow{2}{*}{0,926} \\
\cline { 2 - 5 } \multirow{2}{*}{ Defansif Tip } & Bekar & 20 & 3,084 & 0,27281 & & \multirow{2}{*}{0,221} \\
\cline { 1 - 5 } & Evli & 82 & 2,5976 & 0,47331 & \multirow{2}{*}{$-1,230$} & $0,2,7389$ \\
\cline { 2 - 5 }
\end{tabular}

Yukarıdaki Tablo 6'da medeni durum değişkeni açısından hem karar verme hem de defansif tıp ölçeği genel boyutunda anlamlı bir fark olmadığı tespit edilmiştir ( $p>0,05)$. 
Tablo 7. Araştırmaya Katılanların Karar Verme Stilleri ile Defansif Tıp Tutum Puan Ortalamalarının Çalışılan Birim Değişkenine Ait Varyans Analizi

\begin{tabular}{|c|c|c|c|c|c|c|}
\hline Ölçekler & Çalışılan Birim & $\mathbf{n}$ & Ort. & SS & $\mathbf{F}$ & $\mathbf{p}$ \\
\hline \multirow{4}{*}{ Karar Verme } & Dahili Birimler & 45 & 3,0978 & 0,34129 & \multirow{3}{*}{0,534} & \multirow{3}{*}{0,588} \\
\hline & Cerrahi Bilimler & 40 & 3,0540 & 0,39009 & & \\
\hline & Temel Tıp Bilimleri & 17 & 3,1576 & 0,27476 & & \\
\hline & Çalışılan Birim & $\mathbf{n}$ & Ort. & SS & & \\
\hline \multirow{3}{*}{ Defansif Tıp } & Dahili Birimler & 45 & 2,6185 & 0,44737 & \multirow{3}{*}{1,673} & \multirow{3}{*}{0,193} \\
\hline & Cerrahi Bilimler & 40 & 2,5583 & 0,51025 & & \\
\hline & Temel Tıp Bilimleri & 17 & 2,8007 & 0,34194 & & \\
\hline
\end{tabular}

Tablo 7 incelendiğinde araştırmaya katılan hekimlerin çalıştıkları birim ile defansif tıp ve karar verme stilleri ortalamaları arasında bağımsız gruplarda varyans analizi yapılmıştır. Hekimlerin çalıştıkları birim ile defansif tıp $(F=1,673, p=>0,05)$ ve çalıştıkları birim ile karar verme $(\mathrm{F}=0,534, \mathrm{p}=>0,05)$ arasında anlamlı bir fark olmadı $\breve{\mathrm{g}}$ tespit edilmiştir.

Tablo 8. Araştırmaya Katılanların Karar Verme Stilleri ile Defansif Tıp Tutum Puan Ortalamalarının Hekim Olarak Çalışma Süresi Değişkenine Ait Varyans Analizi

\begin{tabular}{|c|c|c|c|c|c|c|}
\hline Ölçekler & Hekim Olarak Çalışma Süresi & $\mathbf{n}$ & Ort. & SS & $\mathbf{F}$ & $\mathbf{p}$ \\
\hline \multirow{4}{*}{ Karar Verme } & $0-5$ y1l & 14 & 2,9457 & 0,25570 & \multirow{3}{*}{1,591} & \multirow{3}{*}{0,209} \\
\hline & $6-10$ y1l & 26 & 3,0785 & 0,32249 & & \\
\hline & 11 y1l ve üstü & 62 & 3,1284 & 0,37468 & & \\
\hline & Hekim Olarak Çalışma Süresi & $\mathbf{n}$ & Ort. & SS & $\mathbf{F}$ & $\mathbf{p}$ \\
\hline \multirow{3}{*}{ Defansif Tıp } & $0-5$ y1l & 14 & 2,6310 & 0,33871 & \multirow{3}{*}{0,421} & \multirow{3}{*}{0,657} \\
\hline & $6-10$ y1l & 26 & 2,6944 & 0,41433 & & \\
\hline & 11 y1l ve üstü & 62 & 2,5950 & 0,50522 & & \\
\hline
\end{tabular}

Tablo 8 incelendiği zaman hekim olarak çalışma süreleri ile defansif tıp $(\mathrm{F}=0,421$; $\mathrm{p}=>0,05)$ ve karar verme stilleri $(\mathrm{F}=1,591 ; \mathrm{p}=>0,05)$ arasında anlamlı bir fark olmadığ 1 tespit edilmiştir.

Tablo 9'da hekimlerin karar verme algısı ile defansif tıp tutumları arasındaki ilişki verilmiştir. Buna göre karar verme algısı ile defansif tıp arasında negatif yönde düşük düzeyde anlamlı bir ilişki tespit edilmiştir $(r=-, 229 ; p<0,05)$. Karar vermenin alt boyutları ile rasyonel karar verme ve anlık karar verme arasında negatif yönlü düşük düzeyde anlamlı bir ilişki tespit edilmiştir $(r=-, 232 ; p<0,05$ ve $r=-257 ; p<0,01)$. Karar verme ölçeğinin alt 
boyutlarından anlık karar verme ile bağımlı karar verme arasındaki ilişkinin düzeyi, diğer boyutlar arasındaki ilişki düzeyinden daha yüksektir $(r=, 393)$.

Tablo 9. Karar Verme Stilleri ve Alt Boyutları ile Defansif Tıp ve Alt Boyutları Arasındaki Pearson Korelasyon Analizi $(\mathrm{N}=102)$

\begin{tabular}{|c|c|c|c|c|c|c|c|c|c|c|c|}
\hline \multicolumn{2}{|l|}{ Ölçekler ve Alt Boyutları } & 1 & 1.1. & 1.2. & 1.3 . & 2 & 2.1. & 2.2 & 2.3 & 2.4 & 2.5 \\
\hline \multirow[t]{2}{*}{ 1. DefansifTip } & $\mathrm{r}$ & 1 & $800^{* *}$ &, $815^{* *}$ & $259^{* *}$ &,$- 229^{*}$ & ,031 &,- 162 &,$- 232^{*}$ &,$- 257^{* *}$ &,- 190 \\
\hline & $\mathrm{p}$ & & ,000 &, 000 &, 008 &, 021 &, 754 &, 103 &, 019 &, 009 &, 056 \\
\hline \multirow[t]{2}{*}{ 1.1. Pozitif Defansif Tıp } & $\mathrm{r}$ & & 1 &, $322^{* *}$ & 088 &,$- 201^{*}$ & ,057 &,- 141 &,$- 230^{*}$ &,$- 204^{*}$ &,$- 253^{*}$ \\
\hline & $\mathrm{p}$ & & & 001 & ,381 & ,043 & ,567 & ,158 & 020 & ,039 &, 010 \\
\hline \multirow[t]{2}{*}{ 1.2. NegatifDefansif Tip } & $\mathrm{r}$ & & & 1 & , 147 &,- 183 &,- 023 &,- 103 &,- 153 &,$- 220^{*}$ &,- 064 \\
\hline & $p$ & & & & ,139 & ,066 &, 815 &, 305 & ,124 &, 027 &, 520 \\
\hline \multirow[t]{2}{*}{ 1.3. Bilgi Düzeyi } & $r$ & & & & 1 &, 011 & ,098 &,- 138 &,- 022 &,- 020 &,- 003 \\
\hline & $\mathrm{p}$ & & & & & ,909 & ,330 &, 166 &, 828 &, 840 &, 973 \\
\hline \multirow[t]{2}{*}{ 2. KararVerme } & $r$ & & & & & 1 & $.575^{* *}$ & , $417^{* *}$ &, $643^{* *}$ &, $610^{* *}$ &, $477^{* *}$ \\
\hline & $p$ & & & & &. &, 000 &, 000 &, 000 &, 000 &, 000 \\
\hline \multirow[t]{2}{*}{ 2.1. KaçınmaKararVerme } & $r$ & & & & & & 1 &,$- 282^{* *}$ & ,233* &,- 020 & ,018 \\
\hline & $\mathrm{p}$ & & & & & & &, 004 & ,018 &, 843 & ,861 \\
\hline \multirow[t]{2}{*}{ 2.2. SezgiselKararVerme } & $r$ & & & & & & & 1 &, $266^{* *}$ &, $373^{* *}$ &, $244^{*}$ \\
\hline & $p$ & & & & & & & & ,007 & ,000 & ,014 \\
\hline \multirow[t]{2}{*}{ 2.3. RasyonelKararVerme } & $r$ & & & & & & & & 1 &, $217^{*}$ &, $232^{*}$ \\
\hline & $p$ & & & & & & & & & ,028 & ,019 \\
\hline \multirow[t]{2}{*}{ 2.4. AnlıkKararVerme } & $\mathrm{r}$ & & & & & & & & & 1 &, $393^{* *}$ \\
\hline & $p$ & & & & & & & & & &, 000 \\
\hline \multirow[t]{2}{*}{ 2.5. BağımlıKararVerme } & $\mathrm{r}$ & & & & & & & & & & 1 \\
\hline & $\mathrm{p}$ & & & & & & & & & & . \\
\hline
\end{tabular}

Tablo 10. Defansif Tıp Uygulamalarının Karar Verme Stillerini Etkilemesi

\begin{tabular}{|l|l|c|c|c|c|c|c|c|}
\hline Bağımlı Değişken & Bağımsız Değişken & $\mathbf{B}$ & $\mathbf{s h}$ & $\mathbf{t}$ & $\mathbf{F}$ & $\mathbf{R}$ & $\mathbf{R}^{\mathbf{2}}$ & $\mathbf{p}$ \\
\hline \multirow{2}{*}{ Karar Verme Stilleri } & Sabit & 3,546 &, 197 & 18,012 & \multirow{2}{*}{5,520} & \multirow{2}{*}{, 229} & \multirow{2}{*}{, 052} & $0,21^{*}$ \\
\cline { 2 - 9 } & Defansif Tıp & $-0,10$ &, 004 & $-2,349$ & & \\
\hline
\end{tabular}
$* \mathrm{p}<0,05$ (İstatistiksel Anlamlılık Değeri)

Defansif tıp uygulamalarının hekimlerin karar verme stillerini etkileyip etkilemediğini belirlemek amacıyla yapılan regresyon analizi sonuçları Tablo 10'da verilmektedir. Analiz sonucunda kurulan regresyon modeli anlamlı bulunmuştur $(\mathrm{F}=5,520 ; \mathrm{p}<0,05)$. Buna göre defansif tıp uygulamaları, karar verme stillerini $(B=3,546(-0,10) ; p<0,05)$ ters yönde etkilemektedir. Regresyon modeline göre karar verme stillerinin \%5,2'sini defansif tıp uygulamaları açıklamaktadır. Dolayısıyla "Defansif tıp uygulamaları, karar verme stillerini etkilemektedir." hipotezi kabul edilmiştir. 


\section{TARTIŞMA VE SONUÇ}

Hekimler, yaptıkları işin gereği olarak tanı ve tedavi işlemleri sırasında bir karar vermeleri gerekmektedir. Hekimlerin verdikleri kararın defansif yönde olması bazı sorunları da beraberinde getirmektedir. Bu araştırmada, hekimlerin defansif tıp davranışı gösterirken nasıl bir karar verdikleri konusu incelenmiştir. Yapılan analizler neticesinde;

Defansif tıp ile karar verme puan ortalamaları ile cinsiyet ve medeni durum değişkenleri arasında anlamlı farklılık görülmemiştir. Cinsiyet ve medeni durum değişkeninin etkilemediği saptanmıştır.

Araştırmaya katılan hekimlerin karar verme algısı ile defansif tıp puan ortalamalarının çalışılan birim ve hekim olarak çalışma süresine göre anlamlı farklılık bulunmamıştır.

Hekimlerin karar verme ile defansif tıp tutumları arasında negatif yönde düşük düzeyde anlamlı bir ilişki tespit edilmiştir $(\mathrm{r}=-, 229 ; \mathrm{p}<0,05)$. Aynı zamanda regresyon analizi sonucuna göre hekimlerin defansif tıp uygulamaları karar verme stillerini etkilemektedir.

Araştırmaya katılan hekimlerin hastalarına orta ve üzeri derecede defansif davrandıkları görülmüştür. Tıbbi uygulamaları hastalarına daha detaylı açıklayıp açıklamadıkları sorulduğunda ise, \%39,2'si çok katılıyorum cevabını verirken, \%35,3'ü tamamen katıldıklarını belirtmişlerdir. $\mathrm{Bu}$ oranlara bakıldı̆̆ı zaman hekimlerin defansif davrandıkları sonucuna ulaşılmıştır. "Hukuki sorunlardan korunmak için kayıtları daha detaylı tutuyorum" seçeneğine ise $\% 43,1$ 'i çok katıldıklarını \%38,2'si ise tamamen katıldıklarını belirtmişlerdir. \%40,2'si hukuki sorunlardan korunmak için aydınlatılmış onam formlarına daha fazla önem verdiklerini ifade etmişler ve bu ifadeler neticesinde defansif davranışta bulundukları sonucuna ulaşılmıştır. Pirol (2018) tarafından yapılan çalışmada da hekimlerin $\% 87,1$ 'i orta ve üzeri derecede aydınlatılmış onam formlarına daha fazla önem verdiklerini belirmişlerdir. Malpraktis davaları medyada yer aldıkça hekimlerde tedirginliğe sebep olmaktadır ve bu soruya sadece \%4,9’u hiç katılmıorum cevabını vermiştir.

Hekimlik mesleği sürecinde malpraktis nedeni ile dava açılan hekim oranı $(\% 2,7)$ oldukça düşüktür. Konya ilinde 2008 y1lında gerçekleştirilmiş olan bir çalışmada hekimlerin \%87,40'ımalpraktis nedeniyle hiç dava açılmadığını \%9,58'de 1 defa dava açıldığını dile getirmişlerdir (Aynac1, 2008). 
Hekimlerin neredeyse hepsi malpraktis davalarının hekimlik performansına etkisi olacağını düşünmektedirler. Çalışmamızın sonucuyla benzerlik gösteren Aynacı (2008) tarafından Konya ilinde gerçekleştirilmiş olan çalışmada hekimler "Hakkınızda açılacak tıbbi malpraktis davası hekimlik performansınızı etkiler mi?” sorusuna \%38,98“i kesinlikle evet, $\% 45,28$ 'i evet ve \%8,27' si hayır cevabını vermişlerdir.

Araştırmaya katılan hekimlerin çoğunluğu defansif tıp uygulamaları kavramını daha önce duyduklarını belirtmişlerdir. Defansif tıp uygulamaları kavramının içeriği konusunda yeterli bilgiye sahip misiniz? Sorusuna 46 hekim $(45,1)$ evet cevabını verirken 56 hekim $(\% 54,9)$ hayır cevabını vermiştir. Araştırmamızın sonuçlarına göre hekimler defansif tıp konusunda yeterli bilgiye sahip değildir. Araştırmamızın sonuçları ile benzer sonuçlar gösteren çalışmalarda da hayır cevabını veren hekimler fazladır.

\section{5. ÖNERILLER}

Tıbbi hatalardan kaynaklı önemli maliyetlerin yanı sıra kalite ve bakıma erişim üzerindeki olumsuz etkisi de tüm sağlık bakım sistemini olumsuz etkilemektedir. Hükümetler sağlık sistemleri içerisinde reformlar yaparak tıbbi sorumluluk problemine çözüm üretmek zorundadırlar. Sanayileşmiş ülkelerde malpraktis sorunu, gelişmekte olan ülkelere göre daha iyi durumdadır. Düzenleyici yasalar vardır. Önemli bir konu olan tıbbi sorumluluk ve malpraktis için sağlık yöneticileri, doktorlar ve diğer sağlık çalışanlarından tam işbirliği sağlamaları ve örgütsel düzeyde tıbbi meseleleri ele almaları gerekmektedir (Adwok ve Kearns, 2013).

- Tibbi hatalar ve bu hatalar sebebi ile hekimlerin kendilerini defansa alma uygulamaları son yıllarda daha fazla artış gösterdiği için daha fazla çalışma yapılması,

- Defansif tıp konusunda hekimlerin bilgisi yeterli olmadığı için ve yaptıkları kaçınma davranışının defansif tıp uygulaması olduğunu bilmediklerinden ötürü hekimlere gerekli eğitimlerin verilmesi,

- $\quad$ Pozitif defansif tıp davranışı çok fazla mali yüke sebep olduğundan bu konuyla ilgili gerekli önlemlerin alınması

- Negatif defansif tıp davranışlarına neden olan davranışlar hastalar için büyük sorun teşkil ettiği için bu davranışların belirlenip önlem alınması, 
- Hekimler için defansif tıp uygulamaları sırasında davranışlarını denetleyen

bir sistemin kurulması ve hekimlerin sağlıklı karar vereceği ortamın sağlanması önerilmektedir.

\section{KAYNAKLAR}

Adwok, J., Kearns, EH. (2013). Defensive Medicine: Effect on Costs, Quality, and Access to Healthcare. Journal of Biology, Agriculture and Healthcare, ISSN 2225-093X (Online) Vol.3, No.6, 2013

Aynacı. Y. (2008). Hekimlerde Defansif (Çekinik) Tıp Uygulamalarının Araştırılması, Selçuk Üniversitesi, Meram Tıp Fakültesi, Adli Tıp Ana Bilim Dalı, Tıpta Uzmanlık Tezi, Konya. s.2.

Başer A., Kolcu G., Çı̆̆ırgil Y., Kadınkız B., Öngel K. (2014). İzmir Karşıyaka İlçesinde Görev Yapan Aile Hekimlerinin Defansif Tıp Uygulamaları ile İlgili Görüşlerinin Değerlendirilmesi. Smyrna Tıp Dergisi 16:24.

Conroy A. (2006).LessonsLearnedfromthe 'Laboratories of Democracy': A Critique of Federal MedicalLiabilty Reform," Cornell LawRaview. 91(5):1167.

Dedeoğlu. A.K. (2012). Özel Hastanelerde Çalışan Hekimlerin Tıbbi Müdahale ve Tedavide Malpraktisten Doğan Hukuki ve Cezai Sorumluluklarına İlişkin Farkındalık Düzeylerinin Ölçümü: Ankara İli Özel Hastaneler Uygulaması, Atılım Üniversitesi Sosyal Bilimler Enstitüsü Sağlık Kurumları İşletmeciliği Ana Bilim Dalı, Yüksek Lisans Tezi, Ankara.

Null, G, Caroly, D, Feldman M, Rasio, D, Smith D.(2003). Death by Medicine, Nutrition Institute of America, Inc. (NIA, Inc.).

Miller, R. (2006). Problems in health care law (3rd ed). Sudbury, MA: Jones and Bartlett

Ovalı, F. (2010). Hasta Güvenliği Yaklaşımları.Sağlıkta Performans ve Kalite Dergisi, 1 (1), 33-43.

Panting, G. (2005). "Doctors on the Defensive", http://www.theguardian.com/society/2005/apr/01/ health.comment, (Erişim Tarihi: 26 Şubat 2016).

Pirol, M. (2018). Hekimlerin Karar Verme Algılarının Defansif Tıp Tutumları Üzerine Etkisinin Araştırılması, Selçuk Üniversitesi Sağlık Bilimleri Enstitüsü Sağlık Yönetimi Ana Bilim Dalı, Yüksek Lisans Tezi, Konya.

Scott, SG., Bruce, R.A. (1995). Decision making style, the development and of a new measure. Educational and Psychological Measurement, 55(5).

Selçuk, M. (2015). Çekinik (Defansif) Tıp, İzmir Üniversitesi Sosyal Bilimler Enstitüsü Sağlık Hukuku, Yüksek Lisans Tezi, İzmir.

Studdert, D. M., Mello, M. M., Sage, W. M., DesRoches, C. M., Peugh, J, Zapert, K., Brennan, TA. (2005). "Defensive Medicine Among High Risk Specialist Physicians in a Volatile Malpractice Environment", JAMA Internal Medicine, 293(21), 2609-2617.(doi:10.1001/jama.293.21.2609).

Taşdelen, A. (2002). Öğretmen adaylarının farkl psiko sosyal değiş̧kenlere göre karar verme stilleri. (Doktora tezi). Dokuz Eylül Üniversitesi, Eğitim Bilimleri Enstitüsü, İzmir.

White, K. (2005). Medical Malpractice. A crisis in cost and access. Nursing Management, 36(3), 22-25 